\title{
CONCORDE: VERKRY N HOUVAS OP PERSONEEL
}

\author{
KAPT M. BROEKMAN
}

\begin{abstract}
As part of the South African Defence Force's manpower information system, Project Concorde was initiated about two years ago. Its aim has been to gain a fuller perspective of manpower utilisation with the Defence Force by employing scientifically accountable principles. The project incorporates four phases : job analysis, job description, job evaluation and the computerisation of the information evaluation technique, which centres on the decision-making aspect involved in the particular job. The writer comments on the reasons for the selection of this technique, and briefly discusses the initial work which the members of the Project have conducted at Chief of Staff Personnel.
\end{abstract}

Dit is 'n geskiedkundige gebeurtenis vir Hoof van Staf Personeel in besonder en vir die personeelfunksie van die Suid-Afrikaanse Weermag in die algemeen, het Skout-admiraal R.A. Edwards, SM, Hoof van Staf Personeel, SAW, tydens die implimentering van fase drie (dit wil sê werkevaluasie) van Projek Concorde, gesê.

Ten einde werkevaluasie ten volle te verduidelik, is dit nodig om eers kortliks die agtergrond van die projek te skets asook die raamwerk waarbinne die projek funksioneer.

Projek Concorde het ongeveer twee jaar gelede sy beslag gekry. Die doel is: om binne die raamwerk van die Mannekraginformasiestelsel alle werk wat deur lede van die Suid-Afrikaanse Weermag (tans slegs Staandemaglede vanweë die omvang van die taak) gedoen word, in perspektief te stel sodat die Weermag se personeelfunksie op 'n wetenskaplik verantwoordbare grondslag uitgevoer kan word.

Die projek, wat ook as die werkinformasiestelsel bekend staan, funksioneer as 'n sub-stelsel van die Suid-Afrikaanse Weermag mannekraginformasiestelsel. Die mannekraginformasiestelsel is daarop toegespits om informasie omtrent die werk, die werker en die organisasie waarbinne die werk plaasvind, te verskaf.

Gesien teen die agtergrond en die raamwerk waarbinne die projek funksioneer, met inagneming die doel van die projek, is daar besluit om op 'n gedesentraliseerde basis te werk met sentrale. beheer. Daar is bv elke Gevegs-/Ondersteuningsdiens en Stafafdeling 'n Staande Mag-verteenwoordiger met ' $n$ aantal Nasionale Dienspligtiges om die taak aldaar te verrig, aangestel.

Die hele projek, se werkverrigting bestaan uit vier fases:
Werkontleding. Dit is die vasstelling van die funksies en take waaruit poste bestaan asook die werkspesifikasies en wel deur middel van onderhoudvoering en/of waarneming.

Werkbeskrywing. Dit is die proses waardeur die verkreë werksdata tot 'n relatief objektiewe meer (bruikbare), formaat gereduseer word.

Werkevaluasie. Dit is die tegniek om die relatiewe waarde van poste binne 'n organisasie sistematies te bepaal.

Rekenarisering. Dit is die berging van alle inligting aangaande die werk op 'n sinvolle wyse ten einde verskillende personeelfunksies te kan verrig.

\section{Werkevaluasie}

Daar is verskeie tegnieke wat gebruik kan word vir werkevaluasie, die finale keuse berus op die doel waarvoor poste evalueer word.

$\mathrm{Na}$ deeglike navorsing is daar besluit om die Pattersonevaluasie tegniek te gebruik. Die rasionaal waarop die tegniek berus is dat die faktor bes/uitneming eie is aan alle soorte van werk en dat, ongeag die soort en hierargiese posisie van werk/ poste in die organisasie, almal met behulp van dieselfde tegniek geëvalueer kan word.

Die belangrikste voordele van die tegniek is:

a. Dat dit eenvoudig en maklik verstaanbaar is.

b. Dat deelname deur alle partye tydens implementering moontlik is.

c. Dat alle personeel, ongeag ras, geslag en posisie binne die organisasie, op dieselfde wyse beoordeel word.

d. Die lae koste van implementering.

e. Dit kan gou en maklik toegepas word.

Hierdie voordele en nog talle ander was een van 


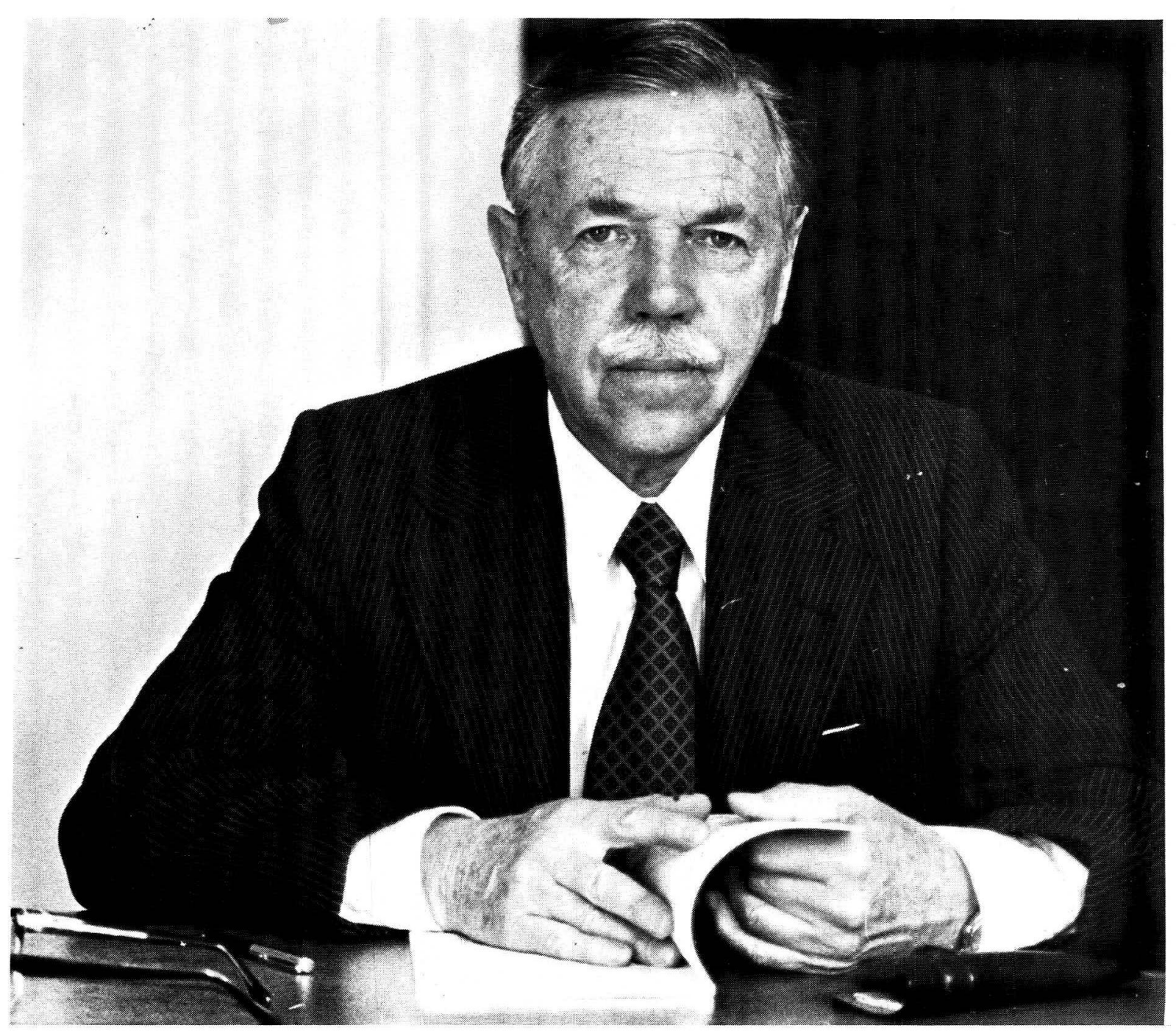

Dr. W. Hudson van (Anglo American Korporasie) wat op vrywillige basis as konsultant opgetree het.

die oorwegende faktore waarom daarop die stelsel vir die Suid-Afrikaanse Weermag besluit is.

Binne 'n organisasie is daar ses basiese vlakke van besluitneming wat alle werk omskryf. Hierdie vlakke is:

Vlak F:Beleid (Topbestuur)

E:Programmeer (Seniorbestuur)

D:Vertolk (Middelbestuur)

C:Roetine (Geskoold)

B:Outomaties (Halfgeskoold)

A:Omskryfde (Ongeskoold)

Elk van hierdie vlakke is goed omskryf en met behulp van die werkbeskrywing van elke pos (meer spesifiek die take) word daar 'n relatiewe waarde aan poste gekoppel. Daar bestaan ook 'n verdere verfyning om die besondere behoeftes van die organisasie in aanmerking te neem.
Aangesien Fase 1 en 2 reeds by Hoof van Staf Personeel afgehandel is, is daar besluit om die tegniek eers daar toe te pas om moontlike leemtes uit te stryk alvorens dit verder uitgebrei word na die ander Gevegs-/Ondersteuningsdienste en Stafafdelings.

Tydens die fisiese implementering van die Patterson-evaluasie tegniek by Hoof van Staf Personeel het $\operatorname{Dr} W$. Hudson van Anglo American Korporasie op vrywillige basis as konsultant opgetree. Sy omvangryke kennis en ondervinding van die tegnieke het daartoe bygedra dat alle onder-offisiersposte in drie dae afgehandel kon word. Die Komitee wat vir die evaluasie verantwoordelik was, het bestaan uit: Brigadier J.A. van Niekerk, Adjunk Hoof van Staf Personeel, as Voorsitter, asook verteenwoordiger uit die onder-offisiersgeledere binne direktorate met Dr W. Hudson as tegniese adviseur. 


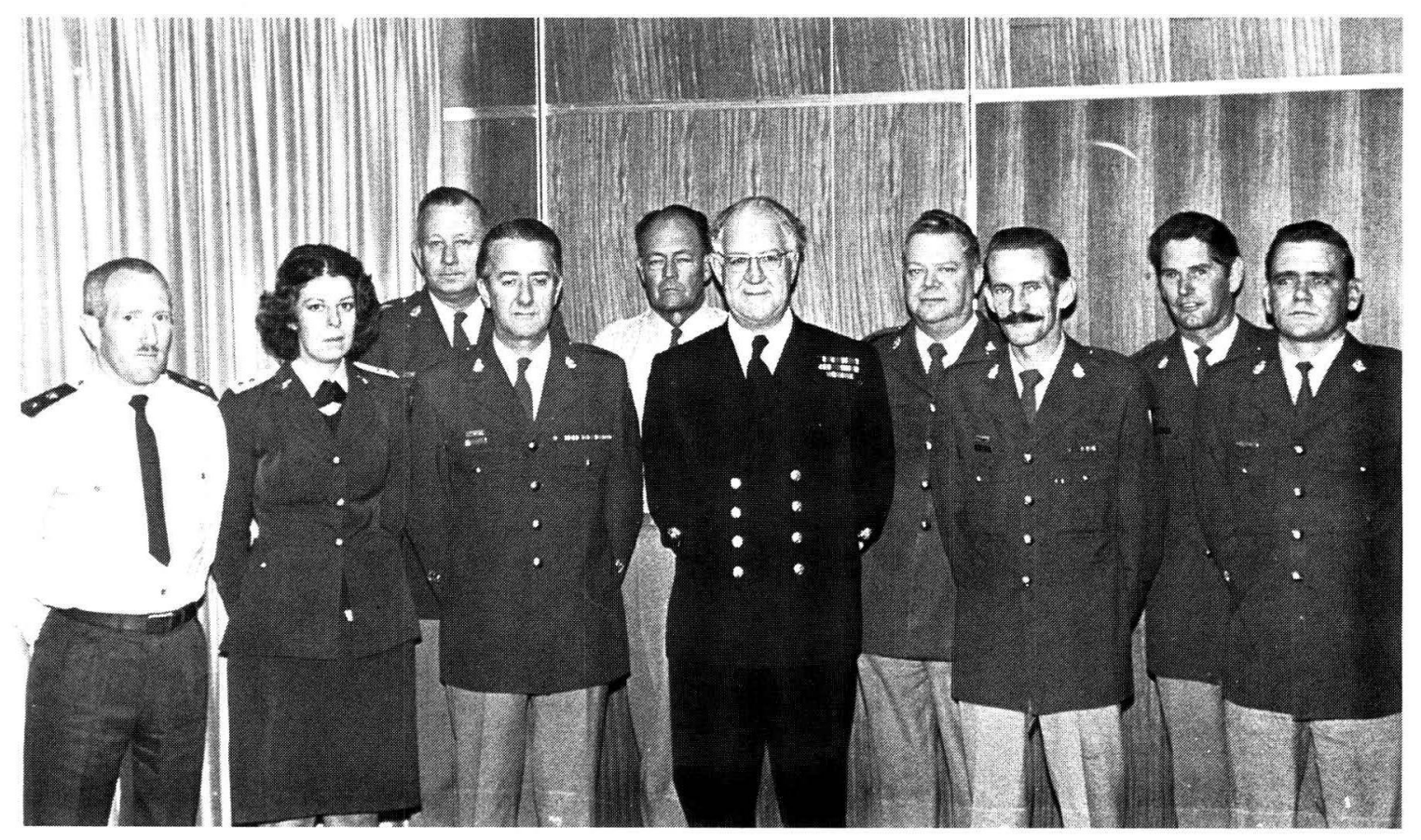

Deeknemers wat verantwoordelik was vir die evaluering van die onderoffisier poste by HSP. Van links na regs: Kmdt W.E. Bond (Projekleier), Kapt M.C. Broekman (projeklik), AO II G.F. Grobler (DNDA), AO I S.J. Pienaar (DNDA), AO II H.L. Robbertse (DAPA), S Adm R.A. Edwards, SM (HSP), AO II C.A.C. Viviers (DP) AO II J.A. de Beer (DNDA), AO I O. van Niekerk (DSLO), AO I J.P. de Kooker (DMV).

Die evaluasie van die onder-offisiersposte by Hoof van Staf Personeel word allerweë as suksesvol beskou en het alreeds verskeie leemtes in die organisasie onder andere wanaanwending van personeel, uitgewys.

Daar is vanaf 19 Junie evaluering van offisiersposte by Hoof van Staf Personeel gedoen. Die voorafgaande evaluering asook die evaluering van die Direkteurposte behoort teen die einde Junie voltooi te wees.
Projek Concorde sal na voltooiing, bo alle twyfel, daartoe bydra dat die personeelfunksies in die Suid. Afrikaanse Weermag op 'n meer wetenskaptik verantwoordbare grondslag uitgevoer kan word.

Daar is ook al by KMG met evaluasie ' $n$ ' aanvang geneem en dit blyk dat die Patterson-evaluasie tegniek met groot sukses in die SAW toegepas kan word. Na voltooiing van die ander fases by die oorblywende Gevegs-/Ondersteuningsdienste en Stafafdelings sal die tegniek ook daar toegepas word. 